Jan Szymczak

\title{
Pojedynki rycerskie, czyli rzecz o sqdzie bożym w Polsce Jagiellonów
}

\section{Ritterduelle, oder vom Gottesgericht in Polen der Jagiellonen}

1. Pojedynek sądowy. 2. Prywatny pojedynek honorowy. 3. Wyzwanie na pojedynek. 4. Związek 20 rodów w obronie honoru. 5. Pojedynki zbiorowe. 6. Miejsce pojedynku w kulturze rycerskiej. 7. Opinie współczesnych o pojedynkach. 8. Przepisy przeciw pojedynkom w XVI w.

1. Gerichtsduell. 2. Privates Ehrenduell. 3. Herausforderung zum Duell. 4. Vereinigung von 20 Familien zum Ehrenschutz. 5. Sammelduelle. 6. Der Duellort in der Ritterkultur. 7. Gegenwärtige Meinungen über Duelle. 8. Vorschriften gegen Duelle im XVI Jahrhundert.

1. Genezy pojedynku upatruje się w sądach bożych, u podłoża których leżało przekonanie, iż czyste żywioły natury zdradzą przestępcę, a bóstwa użyczą pomocy osobie sprawiedliwej lub pokrzywdzonej. Pogląd ten byl rozpowszechniony $w$ średniowieczu, kiedy próby wody i żelaza - zwane ordaliami - zostały wprowadzone do przewodu sądowego. Natomiast właściwy sąd boży stanowił pojedynek, tj. „duellum”, który należał do oficjalnie zalegalizowanych środków dowodowych'. Wykorzystywano go nie tylko w sprawach karnych, ale również cywilnych, w celu oczyszczenia się od przedstawionego oskarżenia, zazwyczaj w sytuacji braku bezpośredniego dowodu winy obwinionego ${ }^{2}$.

' Zob. R. H ube, Wiadomość o sqdach bozych czyli ordaliach $w$ dawnej Polsce, Biblioteka Warszawska 1868, 1. 3 (og. zb. 1. 111), s. 312-316; J. Rozenblatt, Rzecz o pojedynku, Lwów 1879, s. 40-42; A. Winiarz, Sqdy boże w Polsce, KH 1891, R. V, s. 290-291; J. P a y g e r t, Rzut oka na dzieje pojedynku jako przestepstwa, Lwów 1912, s. 8; S. K u t r ze ba, Dawne polskie pravo sqdowe w zarysie, Lwów 1921, s. 81; J. B a rdach, Historia pánstwa i prawa Polski, t. I: Do polowy XV wieku, Warszawa 1964, s. 353; B. S zy nd ler, Pojedynki, Warszawa 1987 , s. 34.

${ }^{2}$ H. N ot t a r p, Gottesurteilstudien, München 1956, rozdz. I; W. S c hild, Alte Gerichtsbarkeit. Vom Gottesurteil bis zum Beginn der modernen Rechtsprechung, München 1980, s. 20. 
2. Od XIV w. „,uellum" w coraz większym stopniu przejmowało funkcje pozasądowego środka obrony honoru, wykorzystywanego w celu odwrócenia od siebie potwarzy lub pomszczenia doznanej krzywdy. Nastąpiła zatem fuzja zjawiska o starej metryce z nową ideq walki rycerskiej ${ }^{3}$. Jakkolwiek nabral on charakteru pojedynku prywatnego, to jednak wymuszał publiczne uznanie pełnej wartości człowieka zagrożonej takim samym publicznym pohańbieniem czci. Jego sakralny charakter wyrażał się przekonaniem, iż tylko krew zmywa plamę na honorze, a więc stanowił rytualną formę ludyczną. Gdy cesarz Karol IV obraził mocnymi słowami cześć Elżbiety Lokietkówny - matki króla węgierskiego Ludwika, posłowie tego ostatniego gotowi byli stanąć do równej walki i pojedynku (duellum et certamen) w obronie swego króla i jego matki, gdyż tę zniewage można zmazać tylko krwią (sanguine dilui) ${ }^{4}$. Bez wzglçdu zresztą na proweniencję pojedynku skupial on w sobie zarówno dowód prawa, jak i bożą łaskę . Działo się tak pomimo potępienia przez papieża Grzegorza XI w $1373 \mathrm{r}$. artykułów prawa saskiego i magdeburskiego, traktujących o ordaliach. Odnosiły się one wszakże do mieszczan i chłopów, toteż szlachta nie poczuwała się do zrezygnowania $z$ sądów honorowych, które zwyczajowo zaczęly stawać się jakby jej przywilejem stanowym. Nie ma natomiast podstaw do stwierdzenia, że stanowily one treść prawa rycerskiego (ius militare) ${ }^{6}$, albowiem dopiero w zaawansowanej monarchii stanowej nabrały one charakteru honorowego pojedynku szlacheckiego.

W jakiejś mierze potwierdzają to akty nobilitacyjne, w świetle których świeżo nobilitowani oraz ich potomkowie nie mieli już obowiązku pojedynkowania się ze stojącym niżej na drabinie społecznej przeciwnikiem? ${ }^{7}$. Dawniejszy sąd boży dopuszczal taką możliwość, pomijając istniejącą wówczas instytucję zastępcy. Zamykanie się stanów radykalnie zmieniło prawa rządzące pojedynkiem, co znalazło wyraz $w$ postanowieniach statutu warckiego z 1423 r., które pozbawily chłopa prawa do nagany szlachcica ${ }^{8}$.

${ }^{3}$ W. I wań czak, Tropem rycerskiej przygody. Wzorzec rycerski w piśmiennictwie czeskim XIV wieku, Warszawa 1985, s. 155.

4 J. Dług osz, Annales seu cronicae incliti Regni Poloniae, ks. 10, Warszawa 1978, s. 314.

5 J. H u izing a, Homo ludens. Zabawa jako zródlo kultury, tłum. M. Kurecka i W. Wirpsza, Warszawa 1985 , s. $137-139$.

${ }^{6}$ Ustalenia Z. Wojci e ch ow sk i e go (Prawo rycerskie w Polsce przed statutami Kazimierza Poznań 1928) próbował uzupełnić K. Górski (Sprawa Janusza Moszewskiego i ,polskie prawo rycerskie", [w:] Ars historica. Prace z dziejów powszechnych i Polski, Poznań 1976, s. 519) O prawo regulowania pojedynkiem spraw honorowych między rycerzami; zob. H. Łow mianski, Poczqtki Polski, t. VI, cz. 2, Warszawa 1985, s. 627.

Zob. W. I wańczak, Tropem.., s. 156.

* W. S e mk ow ic z, Nagana i oczyszczenie szlachectwa w Polsce XIV i XV wieku, Warszawa 1899 , s. 16-18. 
O kilku pojedynkach wspomina Jan Dlugosz. W jego Annales pod rokiem 1389 czytamy, że Gniewosz z Dalewic - podkomorzy krakowski, usiłował fałszywymi pomówieniami splamić cześć królowej Jadwigi. Jej obrony podjął się Jan z Tęczyna - kasztelan wojnicki, przekonany przysięgą, że nie znała ona niczyjego łoża oprócz swego męża i postawił 12 rycerzy, którzy byli gotowi pojedynkiem (duello) bronić niewinności królowej9. Jeśli pominiemy kwestię wiarygodności tego przekazu, jako opisu rzeczywistego przebiegu wydarzen ${ }^{10}$, to musimy uznać, że poświadcza on dalsze respektowanie pojedynku jako środka dowodowego w celu obalenia oskarżenia, $\mathrm{i}$ to już po potępieniu ordaliów przez papieża Grzegorza XI.

W rachunkach dworu Wladysława Jagiełły i Jadwigi pod datą 5 maja $1390 \mathrm{r}$. (czwartek) odnotowano wydatki związane z pojedynkiem pomiędzy niejakim Tomaszkiem a Piotrem Kmita - synem zabitego w 1376 r. starosty krakowskiego Jana. Jakkolwiek zapiska jest bardzo lakoniczna i nie dostarcza wielu informacji, to jednak fakt odbycia się walki jest pewny. Działo się to w Nowym Mieście Korczynie, dokąd $z$ tej okazji zjechało wielu podejmowanych przez królową Jadwigę gości, qui convenerant propter Kymitte et Thomaszconis duellum ${ }^{11}$. Przybyli wówczas $\mathrm{m}$. in. kanclerz Zaklika z Międzygórza, kasztelan krakowski Dobiesław z Kurozwęk oraz ochmistrz dworu królowej Krystyn z Ostrowa. Na skromnym zazwyczaj stole znalazły się wykwintne potrawy, a wszystko w celu uświetnienia całej imprezy ${ }^{12}$, tym atrakcyjniejszej, że związanej $z$ oczekiwaniem dużej porcji emocji. Udział królowej Jadwigi $w$ tego typu widowisku mamy poświadczony jeszcze w 1394 r., kiedy w wigilię św. Michała (poniedziałek 28 września) podejmował ją obiadem propter duellum mieszczanin krakowski Winko z Gdańska - bachmistrz w żupach solnych ${ }^{13}$.

Nie bywal natomiast na takich imprezach Władysław Jagiełło, który chyba nie gustował $w$ tego typu widowiskach ${ }^{14}$. Ale jakby na ironię losu życie nie skąpiło mu przeżyć związanych $\mathrm{z}$ pojedynkami i zdawaniem się na ich wynik. Gdy w 1431 r. Jan Strasz z Białaczowa h. Odrowąż został

${ }^{9}$ J. Długosz, Annales..., ks. 10, Warszawa 1985, s. 177; por. J. Lelewel, Pojedynki w Polszcze, Poznań 1857, s. 8; S. Kutrzeba, Pojedynki w Polsce, Kraków 1909, s. 20-21.

${ }^{10}$ W. Maciejewska, Jadwiga królowa polska. Monografja historyczna, Kraków 1934, s. 76-77, przyp. 66; Rozbiór krytyczny Annalium Poloniae Jana Dlugosza z lat 1385-1444, opr. S. Gawęda, K. Pieradzka, J. Radziszewska, K. Stachowska, pod kier. J. Dąbrowskiego, Wrocław-Warszawa-Kraków 1961, s. 24; H. K ręt, Dwór królewski Jadwigi i Jagielly, Kraków 1987 , s. 128.

${ }^{11}$ Rachunki dworu króla Wladyslawa Jagielly $i$ królowej Jadwigi z lat 1388 do 1420, wyd. F. Piekosiński, Kraków 1896, s. 145.

12 H. Kręt, Dwór królewski..., s. 143.

13 Rachunki królewskie z lat 1393-1395 i 1412. Rachunki podrzęctwa krakowskiego. Rachunki stacji nowosqdeckiej, wyd. H. Wajs, Warszawa 1993, s. 108.

${ }^{14}$ H. Kręt, Dwór królewski..., s. 142. 
postawiony przed specjalnym sądem rycerskim pod zarzutem oczerniania królowej Zofii ${ }^{15}$, w celu jego odparcia wyraził on gotowość wystąpienia obyczajem rycerskim $z$ bronią $w$ ręku przeciwko swym adwersarzom, wśród których byli m. in. Wojciech Malski - kasztelan lęczycki i ochmistrz dworu królowej, oraz Mszczuj ze Skrzynna, Klemens Wątróbka ze Strzelec i Piotr z Kurowa. Po czym - jak odnotowal J. Dlugosz - przez wyciągnięcie ręki prawej na dowód niewinności pozywał każdego z oskarżycieli na pojedynek, a gdy nikt nie podjął jego wyzwania, sędzia nakazał mu wykonanie przysięgi oczyszczającej ${ }^{16}$.

3. Z oznaczającym gotowość do stoczenia walki w obronie swego honoru gestem wyciągnięcia ręki spotykamy się ponownie w 1488 r., kiedy przechwycony przez Marcina Ponieckiego kurier krzyżacki Janusz Moszewski oskarżył go o fałszerstwo listów, i jako dobry rycerz wyciągnął dłoń przed królem i innymi panami. Było to wyzwanie ,na rękę", czyli żądanie pojedynku sądowego ${ }^{17}$.

Wyzwanie na pojedynek miało nieraz formę pisemną. Znany jest list, jaki Jan Głowacz z Oleśnicy wystosował do rycerza śląskiego Konrada Niemcza de Geersdorf, który nie dotrzymał słowa danego 10 października 1410 r. pod Koronowem ${ }^{18}$, że już nigdy nie będzie wspomagał Krzyżaków przeciwko Polsce i jej królowi ${ }^{19}$.

Wzory takich listów sporządzano również w kancelarii królewskiej. Warto zatem zapoznać się z jednym takim uzasadnieniem decyzji o stoczeniu walki w schyłkowym okresie panowania Władysława Jagiełły. Nobilis vir, frater karissime i dalej również w języku lacińskim: Ponieważ Mikolaj cześć moja obelzywa mowa dotknal i naganil moje dobre imie, publicznie mi zarzucając - co z bólem oznajmiam-zdrożności niegodziwe, z tego wzgledu pragnac bardziej życia zbyć niż honoru $i$ godnie bardziej obyczaj wybierajac niz żywot $w$ konfuzji, $z$ tymże moim oszczercq ustalilem reguly starcia $i$ jestem zobowiqzany pojedynkować sie (duellare). Lecz ponieważ naruszenie czci mojej moglo nie mniej niż mnie samego was wzburzyć, dlatego prawdziwe

${ }^{15}$ Jan Strasz z Białaczowa ponoć tylko poręczył za oskarżonego Jana Strasza ze Stanisławowa lub Kościelnik - zob. Rozbiór krytyczny..., L. I, s. 254-255.

${ }^{16} \mathrm{~J}$. Dług osz, Historiae Polonicae libri XII, L. IV-V, [w:] Opera omnia, t. XIII-XIV, Kraków 1877-1878; t. IV, s. 436: manus dextrae protensione, iure purgatus, cum quolibet accusatore duelli pugnam se initurum; zob. S. Kutrzeba, Pojedynki..., s. 20-21.

${ }^{17}$ K. G órski, Sprawa..., s. 518.

${ }_{18}$ Epizod ten opisuje J. Długosz, Annales..., ks. 10-11, Warszawa 1997, s. 153

' Codex epistolaris Vitoldi magni ducis Lithuaniae 1376-1430, cz. II, wyd. A. Prochaska, Kraków 1882, nr MLVII; zob. Zawsze po rycersku, Wiek. Gazeta polityczna, literackí i spoleczna 1878, R. VI, nr 57, s. 2-3; S. Kutrzeba, Pojedynki.., s. 14; B. Szyndler, Pojedynki, s. 36-37. 
braterstwo $i$ braterskie przywiqzanie wam zanosze z usilnq prośbq, abyście $w$ takim dniu do Krakowa zechcieli przybyć z pozostalymi przyjaciótmi, aby wesprzeć mnie $w$ tym wielkim przedsięwzięciu radq $i$ przyjaznq obecnościq $q^{20}$. Uwage zwraca tu przede wszystkim podnoszona już wyżej kwestia publicznego zmazania obrazy honoru, również publicznie naruszonego.

4. Pojedynki $w$ obronie czci były zjawiskiem dość powszechnym $w$ Polsce $\mathrm{XV}$ w., skoro podjęto wówczas pierwsze próby uregulowania ich prawidel i roztaczania nad nimi swego rodzaju spolecznej kontroli. Wkrótce po śmierci Władysława Jagiełły, a więc w okresie pewnego rozprężenia politycznego w kraju, około 1438 r., powstal związek 20 rodów, mający na celu utrzymanie spokoju i zapobieżenie walkom pomiędzy przynależną do nich szlachtą, a w przypadku konieczności odparcia krzywdy - oferujący wzajemną pomoc ze strony Doliwów, Ogonów, Dołęgów, Cholewów, Sulimów, Toporów, Grzymałów, Leliwów, Nałęczów, Leszczyców, Korabów, Rawiczów, Zarembów, Lisów, Kuczabów, Pierzchałów, Dryjów, Półkozów, Ślepowronów i Czelejów. Gdyby ktoś spośród nalezacych do tego zwiazku przez kogośs innego $w$ Królestwie Polskim lub poza jego granicami byl wyzwany do stoczenia pojedynku lub $w$ swym honorze rycerskim zostal zniestawiony, jeśli to osoba zacna, a sprawa, w której dziala, siuszna $i$ wystarczajaco wazna dla obrony honoru, ma on wybrać 2 osoby z tychże rodów, które na wlasny koszt $i$ nie szczędzqc trudu powinny udać sie z nim oraz wspierać go radq $i$ pomoca. A gdyby osoby przezeń wybrane $z$ dopustu bożego zaslably lub innymi ważnymi sprawami byly zajete, inne sobie $w$ ich miejsce dobierze ${ }^{21}$. Podkreślenia wymaga tu przede wszystkim pojawienie się osób towarzyszących wyzwanemu, które w niedługiej przyszłości staną sį̨ nieodzownymi świadkami przeciwników, jako ich sekundanci. Zastapią oni zarówno sędziów, jak i ich urzędników oraz heroldów czuwających nad przestrzeganiem warunków uzbrojenia i przebiegu walki. Zbliża to nas coraz bardziej już do nowożytnej wersji pojedynku.

5. Jak odnotował Jan Długosz, podczas oblężenia Wilna w 1390 r. wspomagający Krzyżaków rycerze francuscy zarzucali Polakom udzielanie pomocy Litwinom. W celu wykazania sluszności swego postępowania obie strony postanowiły, że stoczą między sobą, w równej liczbie po czterech, rycerską

${ }^{20}$ Libri formularum saeculi $X V$, wyd. B. Ulanowski, [w:] Starodawne prawa polskiego pomniki, 1. X, cz. 1, Kraków 1888, nr 41; por. S. Kutrze ba, Pojedynki.., s. 24.

${ }^{21}$ Liber cancellariae Stanislai Ciolek. Ein Formelbuch der Polnischen Königskanzlei aus der Zeit der Husitischen Bewegung, t. II, wyd. J. Caro, Wien 1874, s. 240-241; zob. S. Kut rze ba, Pojedynki..., s. 25. 
walkę (militarem pugnam et duellum) na dworze praskim Wackawa IV Luksemburczyka. Stronę polską mieli reprezentować: Jan z Włostowa - kasztelan dobrzyński, Mikołaj z Wyszmontowa, Jan ze Zdakowa i Jarosław Czech. Jakkolwiek przeciwnicy zjawili się $\mathrm{w}$ Pradze $\mathrm{w}$ określonym czasie i udali się już do zwierzyńca dla popróbowania sił i szczęścia w walce, do pojedynku jednak nie doszło ze względu na mediację króla czeskiego ${ }^{22}$. Sam jednak pomysł dochodzenia swych racji i rozstrzygania wątpliwości orężem nawiązuje wyraźnie do dawnego sądu bożego.

Mamy tutaj do czynienia $\mathrm{z}$ pojedynkiem zbiorowym. Jego geneza nie jest jak dotąd jasna i nasuwają się wątpliwości, czy można go wyprowadzać od sądu bożego. Przykład zbiorowego sądu przekazal Dalimil, który pod rokiem 1315 odnotowal starcie dwóch rodów szlacheckich, po sześciu konnych w pełnym uzbrojeniu $z$ każdej strony, dochodzących sprawiedliwości w sprawie o mężobójstwo. Spotkanie odbyło się w Hradec Králové i trwało cały dzień, aź jeden $z$ rodów uznał się za pokonany ${ }^{23}$. Do annałów historii trafił również słynny Bój Trzydziestu z $1351 \mathrm{r}$. w Bretanii nękanej rywalizacją francusko-angielską. Bretoński szlachcic reprezentujący stronę francuską - Robert de Beaumanoir, wyzwal na pojedynek Bramborougha z ugrupowania anglo-bretońskiego. Wówczas ich poplecznicy wyrazili wolę przyłączenia się do walki, toteż zgodzono się na udział po 30 rycerzy $\mathrm{z}$ każdej strony. Walczono na kopie, miecze, topory i sztylety. Było wielu zabitych, w tym sam Robert de Beaumanoir, a nikt nie wyszedl bez szwanku. Walkę tę sławiono w poezji, malarstwie, a pokrytego bliznami rycerza, który przeżył, Karol V uhonorował najbardziej ze wszystkich gości w 20 lat później ${ }^{24}$. Zbiorowy pojedynek opisal Geoffrey Chaucer w swej opowieści o Rycerzu, każąc swemu bohaterowi przywieść stu zdatnych rycerzy do szranków, zbrojnych jak sie należy $i$ gotowych rozstrzygnąc spór bitwa („,by batayle”) ${ }^{25}$.

Nie była to fikcja literacka, albowiem $z$ taką sytuacją spotykamy siç w 1356 r. Przed bitwą pod Poitiers Geoffrey de Charny zaproponowal, aby zorganizować bój wybranych przez każdą ze stron 100 rycerzy. Do takiej konfrontacji jednak nie doszło, albowiem zaprotestowali sami Francuzi,

22 J. Długosz, Annales..., ks. 10, s. 187. Fakt ten pod rokiem 1394 podają również żródła krzyżackie: Die Chronik Wigands von Marburg, wyd. T. Hirsch, [w:] Scriptores rerum Prussicarum, t. II, Leipzig 1863, s. 660; Johann's von Posilge Chronik des Landes Preussen, wyd. E. Strehlke, [w:] ibidem, t. III, Leipzig 1866, s. 201; por. Rozbiór krytyczny..., 1. I, s. 31; A. F. Gra bski, Polska $w$ opiniach Europy Zachodniej XIV-XV w., Warszawa 1968 , s. $69-70$.

${ }^{23}$ W. I wańczak, Tropem..., s. 155.

${ }^{24} \mathrm{G}$. D u b y, R. M and rou, Historia kultury francuskiej. Wiek $X-X X$, thum. H. Szumańska-Grossowa, Warszawa 1965, s. 188-189; B. W. Tuchman, Odlegle zwierciadlo, czyl rozlicznymi plagami nekane XIV stulecie, thum. M. J. i A. Michejdowie, Katowice 1993, s. 134.

${ }^{25}$ G. Ch a u ce r, Canterbery Tales, London 1950, s. 44; tekst polski wg tłum. P. Mroczkowskiego, Opowieść Rycerza, Kraków 1988, s. 37. 
gdyż zbyt wielu rycerzy wykluczyłoby to $z$ walki, slawy i możliwości zdobycia okupu ${ }^{26}$.

6. Walczący w listopadzie 1410 r. pod Tucholą zaciężni krzyżaccy, posądzeni o ucieczkę $\mathrm{z}$ pola bitwy i tchórzostwo, zwyczajem rycerskim zamierzaja bronić swego honoru na dworach królów i ksiażat, by zbrojnq rekkq oczyścić sie $z$ zarzucanej im winy $i$ hanby, a dla wykazania swej niewinności toczyć ,pugnae atque duelli, ${ }^{\prime 2}$.

Podczas oblężenia Łucka w 1431 r. na niektórych panów polskich padło podejrzenie o dostarczanie obrońcom broni palnej i prochu. Głównego sprawce upatrywano w Wawrzyńcu Zarembie, toteż Stanisław Ćwikła h. Łabędź $z$ Kunina w Sandomierskiem wyzwał go nawet ad duellum ${ }^{28}$. Jeszcze w 1460 r. Jakub Dębiński i Wojciech Górski, wysłani do króla czeskiego Jerzego $\mathrm{z}$ Podiebradów, mieli choćby pojedynkiem (duello et pugna) rozprawić się $\mathrm{z}$ potwarzą rzuconą na Kazimierza Jagiellończyka i królową Elżbietę, odpowiedzialnych jakoby za podpalanie miast w Czechach $^{29}$. Tym samym sposobem próbował oczyścić wielkiego mistrza z zarzutu nielojalności wobec Polski przybyły do Torunia w 1476 r. marszałek krzyżacki Ulryk, wyzywając na duellum każdego, kto rozsiewał takie plotki ${ }^{30}$. Natomiast Jerzy z Podiebradów osobiście chcial siẹ zmierzyć z Maciejem Korwinem w 1471 r., i ta pugna privata w obliczu zebranych wojsk czeskich i węgierskich miała zadecydować o wyniku wojny ${ }^{31}$. Z taką sytuacją spotykamy się od dawien dawna. Warto więc przypomnieć, że Jan Luksemburski wyzwał Kazimierza Wielkiego, kiedy podszedł ze swymi wojskami pod Kraków ${ }^{32}$. Również Władysław Biały oddając w 1376 r. zamek w Złotorii Bartoszowi z Wezemborga, zażąal od niego skruszenia kopii. Ten zgodzil sie na to $i$ oto ksiaże ze swoja kopia przeciwko Bartoszowi, a Bartosz przeciwko ksieciu, rozpędziwszy konie, $z$ wielkq silq rzucili sie jeden na drugiego $i$ ksiąze otrzymal od Bartosza w prawe ramie dosyć powazna rane - jak czytamy w kronice Jana $\mathrm{z}$ Czarnkowa ${ }^{33}$.

W XV w. pojedynki stały się jednym z ważniejszych elementów kultury rycerskiej. Nie dziwi zatem fakt, iż Kazimierz Jagiellonczyk zapisując

${ }^{26}$ B. W. Tuchman, Odlegle zwierciadlo..., s. 147.

27 J. Dlugosz, Historiae..., t. IV, s. 106-107; por. S. K u trzeba, Pojedynki.., s. 26.

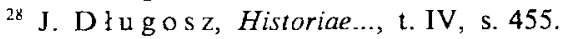

29 Ibidem, t. V, s. 305-306; por. S. Kutrzeba, Pojedynki.., s. 26-27; T. R oje k, Damy, rycerze $i$ dżinsy, Warszawa 1977, s. 64.

30 J. D lugosz, Historiae..., t. V, s. 640.

31 Ibidem, t. V, s. 541 .

${ }^{32}$ W. I wanczak, Tropem..., s. $78-79$.

${ }^{3}$ Jan z Czarnkowa, Chronicon Polonorum, wyd. J. Szlachtowski, [w:] Monumenta Poloniae Historica, t. II, Lwów 1872, s. 660 . 
dominikanom w Brześciu Kujawskim 2 grzywny z dochodów z cła brzeskiego na mszę $w$ intencji zmarłego 20 maja 1454 r. Jakuba $z$ Kobylan - kasztelana gnieźnieńskiego i starosty brzeskiego, zaznaczył w wystawionym 21 września tegoż roku akcie, iż czynami rycerskimi przyczynil się on do pomnożenia honoru królewskiego i Korony Polskiej, uczestnicząc in duellis et astiludiis ${ }^{34}$. A zatem pojedynek został postawiony na równi $\mathrm{z}$ innymi rodzajami walk rycerskich, głównie $\mathrm{z}$ turniejem, i tak jak on cieszył się wysokim prestiżem i uznaniem w społeczności feudalnej. Wśród dworzan Zygmunta I Starego znajdował się nawet biegły w ich przepisach (duellantium et litigantium in aula arbiter) niejaki Neptycki ${ }^{35}$. W $1511 \mathrm{r}$. król zezwolił na pojedynek pomiędzy Mikołajem Turskim i Mikołajem Smolikowskim, wystawiając $\mathrm{z}$ tej okazji specjalną cedułę $e^{36}$. Podane $w$ niej warunki firmował swoją osobą, przykładając do niej własną pieczęć marszałek koronny. Nie jest to przypadek, albowiem to on zarządzal dworem panującego, był mistrzem ceremonii oraz wykonywal sądownictwo karne $\mathrm{w}$ miejscu pobytu króla. $\mathrm{Z}$ podobną sytuacją spotkaliśmy się już w 1488 r., kiedy przechwycony przez Marcina Ponieckiego kurier krzyżacki Janusz Moszewski oskarżył go o fałszerstwo listów i okazał gotowość do stoczenia $z$ nim walki. Wyzwany zwrócil się do Kazimierza Jagiellończyka $\mathrm{z}$ prośbą, aby wolno mu było bronić swej czci, i wówczas na rozkaz władcy marszałek koronny wyznaczył Januszowi Moszewskiemu termin sądowy $w$ celu ustalenia czasu $i$ miejsca pojedynku ${ }^{37}$. Jakkolwiek na jego odbycie nie zezwolono i cała sprawa utonęla $w$ niepamięci, to jednak wykazała ważną rolę, jaką w średniowiecznym pojedynku sądowym odgrywał marszałek koronny.

7. Nie brakło wszakże i zażartych przeciwników takiego sposobu rozwiązywania sporów i pojmowania honoru. Należal do nich m. in. Marcin Kromer, który $\mathrm{w}$ następujących słowach określił duellum sive singulare certamen: Ów barbarzyński bowiem $i$ obcy zalożeniom religii chrześcijanskiej obyczaj wyzywania przeciwnika na pojedynek oraz rozstrzygania mieczem,

\footnotetext{
${ }^{34}$ Codex epistolaris saeculi decimi quinti, t. III, wyd. A. Lewicki, Kraków 1894, dodatek nr 74; por. S. Kutrzeba, Pojedynki..., s. 15; A. Ka miński, Kobylański (Kobyleriski) Jakub $z$ Kobylan, [w:] PSB, t. XIII, 1967-1968, s. 161.

${ }^{35} \mathrm{~K}$. W a rs ze wi cki, De optimo statu libertatis libri duo, Kraków 1598, s. 50; zob. M. D zi eduszycki, Pojedynki, Czas. Dodatek Miesięczny 1857, t. VII, s. 17; T. Czack i, O litewskich $i$ polskich prawach, o ich duchu, źródlach, zwiqzku, i o rzeczach wartych $w$ pierwszym Statucie dla Litwy, 1529 roku wydanym, t. II, wyd. K. J. Turowski, Kraków 1861, s. 159.

${ }^{36} \mathrm{~J}$. Sz y m czak, Cedula na sąd boży z 1511 r., AUL 1992, Folia Historica 44, s. 113-115.

${ }^{37}$ K. Górski, Sprawa..., s. 519-520.
} 
gdzie prawo, a gdzie bezprawie, gdzie prawda, a gdzie falsz, posunięty aż do zabójstwa czy poddania sie przeciwnikowi, nie ma nic wspólnego z sadem ${ }^{38}$. Interesujące spostrzeżenia na temat pojedynków przedstawił Łukasz Górnicki. Charakteryzując idealnego dworzanina, stwierdzil, że musi on być dobrze wyćwiczony w rzemiośle wojennym, aby umial z każdq broniq, tak pieszo, jako $i$ na koniu, a ich wszytki znal $i$ wiedzial fortele, a zwlaszcza tych broni, których najbarziej używajq $u$ dworu. I dalej rozwija ten wątek, podając przyczyny swego stanowiska. Bo izz z zamowy [przymówki] do bitwy przychodzi, a kto ma meskie począ́ sobie, musi nie pragnąc nad nieprzyjacielem mieć góry, ale takie ubrano jako $i$ on, z takoważ broniq jako i on stawić sie na placu, przeto umieć $i$ być gotów na każdy czas do wszytkiego, a nie potrzebować żadnej wymówki ani odwloki - jest to rzecz nieprzeplacona ${ }^{39}$. Zarazem jednak nie chce, aby jego dworzanin do takowej pojedynkiem bitwy byt chciwy, chyba gdzieby mu szlo o poczciwość; abowiem mimo to, iż jest wielkie niebezpieczeństwo (bo a co wiedzieć, komu kostka padnie), kto do tego bez gwaltownej przyczyny skwapliwie bieży, godzien jest, żeby sie jego towarzystwa poczciwi ludzie strzegli. Ale kiedy czlowiek tak daleko $w$ tej mierze zabrnie, iż bez swej wielkiej lekkości cofnqć sie na zad nie może, tam już nielza, jedno konać [dokonać] statecznie swoje przedsiewziecie a we wszystkich rzeczach, tak przed wyjechaniem na plac, jako też $i$ na placu już będac, nie hardzie ani zuchwale, ale śmiele a rzeźwie poczynać sobie sercem niezwycięzonym; bo kto by chcial po daniu rekki szukać dopiro tych dróg, żeby mu się bić nie przyszlo, prawda, żeby uczynil krześcijańskie, ale nie wiem, jako by praw byl zawolaniu rycerskiemu, gdyż ślacheckie slowa nigdy odmienne być nie maja, a jako skalq wiatr nie wlada, tak poczciwego czlowieka usty ani chmiel, ani gniew, ani żal chybać nie $m a^{40}$.

Ł. Górnicki przestrzega tu przed pochopnym wyzywaniem na pojedynek, aby $w$ obliczu konfrontacji nie zaznać goryczy upokorzenia, jak to nieraz bywało $^{41}$. Książę Henryk Lancaster wracając w 1352 r. z wyprawy do Prus, pokłócił się z księciem Ottonem z Brunszwiku i przyjął jego wyzwanie do walki, którą zorganizowano w Paryżu. Załamany jego sławą dygotał jednak tak mocno w siodle, że nie mógł włożyć hełmu i utrzymać kopii. Zdjęto go więc z konia i odwołal wyzwanie. Król francuski Jan II Dobry pogodził przeciwników i zatuszowal całą sprawę oraz zakłopotanie wynikające ze sprzeniewierzenia się zasadom rycerskim ${ }^{42}$.

${ }_{38}$ M. K r omer, Polonia sive de situ, populis, moribus, magistratibus et Republica regni Polonici libri duo 1578, wyd. W. Czermak, Kraków 1901, s. 115. Tekst polski wg: M. K romer, Polska, czyli o polożeniu, ludności, obyczajach, urzẹdach i sprawach publicznych Królestwa Polskiego ksiegi dwie, thum. S. Kazikowski, Olsztyn 1977, s. 149.

${ }^{39}$ L. Górnicki, Dworzanin polski, [w:] Pisma, t. I, opr. R. Pollak, Warszawa 1961, s. 91.

40 Ibidem, s. 92.

t1 Ihidem, s. 209-211; zob. M. Os s o w sk a, Ethos rycerski $i$ jego odmiany, Warszawa 1986, s. 101.

${ }^{4}$ B. T u chm a n, Odlegle zwierciadlo..., s. 141-142. 
8. Zdecydowana postawa papiestwa od końca $X V$ w. na polu zwalczania plagi pojedynków zaczęła przynosić pewne wymierne rezultaty, ale tylko w dziedzinie ustawodawczej. W $1472 \mathrm{r}$. synod kościelny w Toledo odmówił prawa do chrześcijańskiego pogrzebu poległym $\mathrm{w}$ takich walkach. Miało to wpływ na wprowadzenie $w$ wielu krajach ustaw zwalczających to - jak określano - przeciwne prawom boskim i przyrodzonym zjawisko. Pierwszy krok zrobila w 1480 r. w Hiszpanii Izabella Kastylijska, a w 1566 r. również Karol IX wydał we Francji edykt przeciwko pojedynkom. Niebawem ich uczestników uznano za winnych zbrodni zabójstwa oraz obrazy majestatu, co pociągało za sobą karę śmierci. Stało się to za sprawą m. in. uchwał soboru trydenckiego z 1563 r., na mocy których pojedynkujących się dotykała klątwa kościelna ${ }^{43}$.

Pewien postęp $w$ tej dziedzinie odnotowujemy również $w$ Polsce. Na sejmie radomskim w 1505 r., za Aleksandra Jagiellończyka, stosując się do postanowień bulli Grzegorza XI z 1373 r., odjęto czternastu artykułom prawa saskiego i magdeburskiego obowiązująca dotąd moc i zabroniono sędziom stosowanie ordaliów i sądów bożych, w tym także duellum ${ }^{44}$. Przestały one pełnić funkcje środka dowodowego w sądzie, ale nie zmniejszyla się przez to rola pojedynków jako prywatnego sposobu obrony czci.

Pogląd na pojedynki sformułowany został w konstytucji z 1588 r., która potępiła je wprawdzie, ale nie wprowadziła stanowczego zakazu ich odbywania $^{45}$. Nie pomogły represje wobec ich uczestników, których za sam udział czekała kara pół roku wieży, a w wypadku śmierci któregoś z przeciwników - kara za mężobójstwo ${ }^{46}$. Podobnie jak w innych krajach, rygory prawne w Polsce nie zmniejszyły skali zjawiska, którego podstawowe kanony powstały w średniowieczu, a które coraz bardziej rozszerzało się w następnych stuleciach ${ }^{47}$.

${ }^{43}$ J. Rozenblatt, Rzecz o pojedynku, s. 20, 45, 63; J. Paygert, Rzut oka..., s. 12-14; S. Ku trzeba, Pojedynki..., s. 42.

${ }^{44}$ VL, t. I, wyd. J. Ohryzko, Petersburg 1859, s. 153-155; zob. M. Dzieduszycki, Pojedynki, s. 16.

4s Z. K a czmarczyk, B. Leśnodorski, Historia państwa $i$ prawa Polski, t. II: Od polowy $X V$ wieku do $r$. 1795, red. J. Bardach, Warszawa 1966, s. 334-335.

${ }^{46}$ T. Czacki, O litewskich..., t. II, s. 159-160.

${ }^{47}$ Zob. S. Kutrzeba, Pojedynki.., s. 28-32; H. Seitz, Blankwaffen I. Geschichte und Typenentwicklung im Europäischen Kulturbereich von der prähistorischen Zeit bis zum Ende des 16. Jahrhunderts, Braunschweig 1965, rozdz. Das Duell und die Fechtkunst. 